\title{
SOCIAL CITIZENSHIP AND SOCIAL RIGHTS IN AN AGE OF EXTREMES: T. H. MARSHALL'S SOCIAL PHILOSOPHY IN THE LONGUE DURÉE*
}

\author{
JULIA MOSES \\ Department of History, University of Sheffield \\ E-mail: j.moses@sheffield.ac.uk
}

This article demonstrates how T. H. Marshall's conceptualization of sociology-its subject, key questions and methodology —was embedded within broader moments in twentieth-century political history, including two world wars, the economic crisis of the interwar era, the onset of the Cold War and the rise of decolonization. In doing so, it brings intellectual history and the history of academic disciplines (particularly sociology) together with more recent trends in the historiography of twentieth-century Europe, including research on postwar democratization, reconstruction and the global spread of human rights discourses. Marshall was a sociological thinker in what Eric Hobsbawm has called the "age of extremes," whose understanding of social citizenship not only played a role in theorizing the welfare state in postwar Britain, but also helped shape reconstruction within Europe and international development efforts following decolonization. In this respect, Marshall was part of a transnational and global movement to recast key concepts such as democracy, human rights and citizenship after the Second World War. This broader perspective illuminates how his work straddles traditions of pluralism and idealism, liberalism and social democracy, rather than being simply representative of any one of these schools of thought.

Following publication in 1950, Thomas Humphrey Marshall's revised Cambridge lectures Citizenship and Social Class were met with relative silence

This article stems from a conversation with my former supervisor Professor Jose Harris, and it is to Jose that this piece is dedicated. Many thanks to Lawrence Goldman, Stuart Jones, William Whyte, Ben Jackson, Mark Bevir, Michael Freeden and other participants at the conference in honor of Jose held at St John's College, Oxford, for critical comments on an early draft. Thanks, too, to Bob Stern and colleagues in the Ethics of Care Philosophy Seminar at the University of Sheffield for helpful feedback. I am especially grateful to Holger Nehring and the editors and anonymous peer reviewers at Modern Intellectual History for their careful reading of the essay. 
for the next three decades. Sociology appeared to have moved on, as Marshall's historical, qualitative style seemed outdated. In the midst of the Cold War, large-scale quantitative studies and, later, broad historical-comparative studies became the norm, and Marshall's work on citizenship did not sit comfortably within the evolving discipline. Even the growing undercurrent in sociology that prioritized the psychology of individual experience in increasingly affluent societies seemed to travel in a different direction. ${ }^{1}$ Not least, a general movement in Britain away from universalist welfare in the late 1950 s and early 1960 s may have also militated against Marshall's theory of citizenship. ${ }^{2}$ By the 1980s, however, Marshall's arguments about the relationship between citizenship and equality began to attract a broad audience of sociologists and political theorists alike. Amidst economic retrenchment in Britain, the USA and much of Western Europe, Marshall's claims that the twentieth century was the era of social rights found favor with a wide variety of scholars. ${ }^{3}$ Moreover, as debates about the establishment and evolution of the European Union posed new questions about labor migration, minorities and European citizenship, and as a number of global crises revived discussions about the purpose and scope of "human rights," Citizenship and Social Class found a fresh following amongst social scientists and historians alike. ${ }^{4}$

The cycles of popularity of Marshall's work follow broadly the lines of key developments of political history. This article seeks to demonstrate how Marshall's specific conceptualization of sociology - its subject, key questions and methodology — was embedded in these developments, and reflected them, but

Margaret Somers, "Citizenship Troubles: Genealogies of Struggle for the Soul of the Social," in Somers, Genealogies of Citizenship: Markets, Statelessness, and the Right to Have Rights (Cambridge, 2008), 147-70.

$2 \quad$ Jose Harris, "Citizenship in Britain and Europe: Some Missing Links in T. H. Marshall's Theory of Rights," ZeS-Arbeitspapier 2 (2010), at http:hdl.handle.net/10419/43703, accessed 4 March 2012, 21. Nonetheless, some, like Richard Titmuss, continued to favor universalism. Meanwhile, Marshall began pondering an indirect form of means testing through the use of tax benefits.

3 Even if it also found several detractors. See Anthony M. Rees, "T. H. Marshall and the Progress of Citizenship," in Martin Bulmer and Anthony M. Rees, eds., Citizenship Today: The Contemporary Relevance of T. H. Marshall (London, 1996), 1-23; Ben Revi, "T. H. Marshall and His Critics: Reappraising 'Social Citizenship' in the Twenty-First Century," Citizenship Studies 18/3-4 (2014), 452-64.

$4 \quad$ For example, Margaret R. Somers and Christopher N. J. Roberts, "Toward a New Sociology of Rights: A Genealogy of 'Buried Bodies' of Citizenship and Human Rights," Annual Review of Law and Social Science 4 (2008), 385-425; Seyla Benhabib, The Rights of Others: Aliens, Residents and Citizens (Cambridge, 2004); Andreas Fahrmeir, "Die moderne Staatsbürgerschaft und ihre Grenzen: Anmerkungen zu T. H. Marshalls "citizenship"Konzept," Historische Zeitschrift 286 (2008), 640-55; Matthew Grant, "Historicizing Citizenship in Postwar Britain," Historical Journal 59/4 (2016), 1187-1206. 
also made significant contributions to their understanding. In doing so, it brings intellectual history and the history of academic disciplines together with more recent trends in the history of twentieth-century Europe. Marshall was a sociological thinker in what Eric Hobsbawm has called the "age of extremes," and he developed his ideas about the battle between communism, fascism, liberalism and social democracy in the context of the two postwar moments of democratization and reconstruction. ${ }^{5}$ Marshall's understanding of social citizenship played a role in theorizing the welfare state in Britain. Yet it also shaped reconstruction within Europe, as well as international development efforts following decolonization. In this respect, Marshall was part of a transnational and global movement to recast key concepts such as democracy, human rights and citizenship after the Second World War. ${ }^{6}$ However, Marshall's concept of social citizenship was not only representative of the postwar moment of 1945. As a prisoner of war in Germany in 1914, he discovered common fellowship borne through internment; as a policy adviser on Germany and general observer during and after the Second World War, he witnessed firsthand the making of a national community in Britain through the "people's war" and the unmaking of the "people's community" under National Socialism. The experience of war proved formative for his social thought, shaping Marshall's understanding of social relations, inequality and national development. This broader context illuminates how his work straddles traditions of pluralism and idealism, liberalism and social democracy, rather than being simply representative of any one of these schools of thought.

By examining T. H. Marshall's intellectual biography, I aim to unpack some of the continuities that cut across this turbulent era, and across national borders, tying postwar European ideas about the welfare state to their nineteenthcentury heritage. In this respect, Marshall's contribution mirrors those of the German émigré intellectuals that defined the "Weimar Century." Like Friedrich Meinecke, who tried in 1945 to understand what he saw as the "catastrophe" of his era, Marshall recast idealist social philosophy from the late nineteenth century in the context of two world wars in order to make sense of the present, but also to

5 For example, Mark Mazower, Jessica Reinisch and David Feldman, eds., Post-war Reconstruction in Europe: International Perspectives, 1945-1949, Past \& Present Supplement 6 (2011).

6 Martin Conway, "Democracy in Postwar Western Europe: The Triumph of a Political Model," European History Quarterly 32/1 (2002), 59-84; Samuel Moyn, The Last Utopia: Human Rights in History (Cambridge, MA, 2010); Stefan-Ludwig Hoffmann, ed., Human Rights in the Twentieth Century (Cambridge, 2011); Sean Forner, German Intellectuals and the Challenge of Democratic Renewal: Culture and Politics after 1945 (Cambridge, 2014).

7 Udi Greenberg, Weimar Century: German Emigrés and the Ideological Foundations of the Cold War (Princeton, 2014). 
provide a normative blueprint for the future. ${ }^{8}$ In part, his thinking resonated with an earlier Continental, and especially German, social philosophy and associated conceptions of social policy, the role of the state and the nature of community. For Marshall, social citizenship stemmed from a specific historical and cultural context, stated in national terms, which was informed by a communitarian sensibility. Citizenship was not universal, and it needed to be cultivated in specific ways according to particular circumstances. Marshall's theory of social citizenship, then, needs to be cast against this larger backdrop, situating his work within broader interwar and early postwar British and transatlantic intellectual history and connecting that history to its nineteenth-century antecedents. Throughout his life, Marshall was occupied personally with developments in Germany. This aspect of his intellectual background may provide us with some clues about his conception of social citizenship and its complex legacy.

Intellectual historians have so far interpreted Marshall's thought primarily in the context of certain strands of British history. But they have by and large overlooked the broader European context as well the elemental ways in which his thought was tied to key challenges in the "age of extremes." Marshall saw himself as an "intellectual" and argued that intellectuals could offer guidance in political and social life. ${ }^{9}$ However, his Cambridge lectures of 1949 set out a plan for recasting society, arguing that social policy could play a pivotal role in "planning" a new form of social relations based on the equality of status. ${ }^{10}$ For this reason, Jose Harris has seen Marshall as emblematic of a transformation that began to take root during the interwar period and would flourish during the early years of the Cold War. It was during this period that social theorists such as Marshall, along with his colleagues at the London School of Economics (LSE) William Beveridge and Richard Titmuss, moved away from embracing systematic social philosophieseven if they retained glimpses of earlier idealist political thought. ${ }^{11}$ Following this logic, Eugenia Low has situated Marshall's understanding of citizenship in a particular culture of British postwar planning that chimed with his professional

8 On idealism in modern Britain see W. J. Mander, British Idealism: A History (Oxford, 2011).

9 T. H. Marshall, "Reflections on the Intelligentsia," $1-17$ in Marshall Papers (MP), 1, 1, British Library of Political and Economic Science (BLPES).

10 T. H. Marshall and Tom Bottomore, Citizenship and Social Class (London, 1992), 39.

11 Jose Harris, "Citizenship in Britain and Europe"; Harris, "Political Thought and the Welfare State 1870-1940: An Intellectual Framework for British Social Policy," Past and Present 135 (1992), 116-41, at 23 n. 20; Harris, "Political Thought and the State," in S. J. D. Green and R. C. Whiting, eds., The Boundaries of the State in Modern Britain (Cambridge, 1996), 15-29, at 25; Harris, William Beveridge: A Biography (Oxford, 1997), especially chap. 19. For a related argument see Stefan Collini, "Sociology and Idealism in Britain, 18801920," Archive of European Sociology 19/1 (1978), 3-50. 
identity as a sociologist, though she also notes that his experiences with Germany shaped his thinking. ${ }^{12}$ Histories of sociology as a discipline have taken a different tack, placing Marshall within a linear narrative of the development of the field rather than engaging critically with his ideas by situating them within the specific context in which he was living and writing. As such, accounts of Marshall as a sociologist have tended to place him neatly in a box with "classics" or the "old guard" of the profession and have failed to chart how exactly his work evolved in rhythm with his complex and international career and how aspects of earlier social thought continued to inform him throughout his life. ${ }^{13}$

Against this backdrop, this article develops its key argument of T. H. Marshall as a sociological thinker in the "age of extremes" in six chronological steps that highlight key themes in his intellectual development. The first section shows how Marshall began to sympathize with a pluralist strand of idealism after his stint as a POW based outside Berlin during the First World War. The second part traces the development of his social philosophy while analyzing National Socialist Germany for the Foreign Office Research Department. The third section situates his lectures on Citizenship and Social Class against the backdrop of postwar reconstruction. It shows how his earlier emphasis on the importance of pluralism, history and community evolved. For Marshall, the welfare state-with social citizenship as its hallmark - synthesized community and the state rather than following an ethos of centralized state planning. The fourth and fifth sections chart how this thinking informed his work as educational adviser at the British Control Commission in Germany and as head of the Social Sciences Department at UNESCO. In both roles, he argued for nationally specific paths to development, which could be fostered by the social sciences. This emphasis may have led him to dismiss the idea of universal human rights, which could have provided a further stage in the typology of rights outlined in his theory of social citizenship. As the final section shows, Marshall's emphasis on the social sciences as a tool for international development proved ironic because his own social-scientific methods were on

12 Eugenia Low, "Class and the Conceptualization of Citizenship in Twentieth-Century Britain," History of Political Thought 21/1 (2000), 114-31; Low, "The Concept of Citizenship in Twentieth-Century Britain: Analysing Contexts of Development," in Peter Catterall, Wolfram Kaiser and Ulrike Walton-Jordan, Reforming the Constitution: Debates in Twentieth-Century Britain (London, 2000), 179-200; Low, "A Tale of Two Citizenships: Henry Jones, T. H. Marshall and the Changing Conceptions of Citizenship in TwentiethCentury Britain" (unpublished D.Phil. thesis, St John's College, University of Oxford, 2000).

13 For example, Mike Savage, Identities and Social Change in Britain since 1940: The Politics of Method (Oxford, 2010), 107-8; Geoff Payne, Robert Dingwall, Judy Payne and Mick Carter, Sociology and Social Research (London, 1981), 23. 
the wane. Nonetheless, the pluralist and historicist principles behind his concept of social citizenship lived on.

\section{DISCOVERING PLURALISM}

Marshall discovered a pluralist strand of idealist thought by chance while an undergraduate. As a civilian internee in Germany during the First World War, and as a history student at Cambridge, he began contemplating how societies function and how social relations relate to questions of equity and rights. As Mark Bevir notes, "pluralism usually contrasts ... with an empirical belief in or normative commitment to a homogeneous nation and a unified sovereign state." For many British pluralists of the late nineteenth century, including F. W. Maitland and Neville Figgis, pluralism seemed to offer an ethical alternative to Benthamite and Fabian utilitarianism, liberal radicalism and individualism as a way to solve social problems. In the form of medieval guilds and other kinds of association, they identified a means to ensure a sense of interpersonal obligation that benefited all members of a community. However, pluralism was a broad church and could work in conjunction with another strand of social thought that had also grown in appeal in Britain in the same period: idealism, which had gained prominence through the writings of G. W. F. Hegel. ${ }^{14}$ Like pluralists, idealists reacted against what they saw as the liberal individualism of their age, characterized by the social dislocation associated with modern capitalism, industrialization and urbanization. However, they "suggested that individuals were part of unified nations and civilizations that developed through history in ways that typically led to statehood." It was through the state, even if associations helped to support it, that solutions to the social upheaval of the nineteenth century could be found. ${ }^{15}$

This idealist-inspired version of pluralism appealed to Marshall in light of his social background and experience as an internee in Germany during the First World War. The son of an architect, his childhood had been spent split between a London residence and a country home in the Lake District. Marshall's family had some connections with the Bloomsbury set, even if he himself never became involved with the group. ${ }^{16} \mathrm{He}$ studied at Rugby, which had also been host to

14 Mark Bevir, "A History of Modern Pluralism," in Bevir, ed., Modern Pluralism: AngloAmerica Debates since 1880 (Cambridge, 2012), 1-20, at 2, 5.

15 David Boucher and Andrew Vincent, British Idealism: A Guide for the Perplexed (London, 2012), 2. See also Sandra den Otter, “'Thinking in Communities': Late Nineteenth-Century Liberals, Idealists and the Retrieval of Community," Parliamentary History 16/1 (1997), 6784.

16 T. H. Marshall, “A British Sociological Career,” British Journal of Sociology 24/4 (1973), 399-408; A. H. Halsey, “T. H. Marshall: Past and Present 1893-1981: President of the British 
the prominent idealists T. H. Green and R. G. Collingwood and the pluralist R. H. Tawney, before attending Cambridge, where he read history. ${ }^{17}$ It was during his studies at Cambridge that he decided to travel in Germany to improve his language skills. He had selected an inauspicious moment in the summer of 1914, resulting in his arrest and transfer to the Ruhleben prisoner-of-war camp in Berlin following the outbreak of war.

Marshall reflected later in life that his time at Ruhleben had proved "the most powerful formative experience of my early years," and its impact can be seen on the development of his sociological thinking. ${ }^{18} \mathrm{He}$ became immersed in camp life during his four years as an internee, studying history, Italian and other subjects in the camp school and teaching in the school along with his history tutor, J. C. Masterman, the Oxford don and, later, a member of MI5. ${ }^{19}$ Although his internment was compulsory, Marshall seems to have enjoyed it. ${ }^{20}$ His positive memories of this period may have been due to the camp's exceptional nature, in which prisoners were fed well, allowed family visits and not subjected to forced labor. As Matthew Stibbe notes, Ruhleben "in many ways resembled a microcosm of the Edwardian metropolis in its heyday." "21 It was his experience in this artificial social environment which proved influential for Marshall as a sociologist. Writing home to his family in 1915 , he declared, "I can't make out whether this camp is the most natural or the most amazing institution imaginable. It is natural in its development, and amazing in its entire disregard of environment." ${ }^{22}$ Marshall was referring to the gradual evolution of different social strata within the camp. While he formed part of the camp's elite, living in a separate barrack with internees who were university-educated, a number of other divisions coexisted at Ruhleben, including separate barracks for Jewish and black prisoners. The German administrators of the camp let the prisoners take charge of many aspects

Sociological Association 1964-1969," Sociology 18/1 (1984), 1-18; Eugenia Low interview with Frances Partridge, 23 Sept. 1996, cited in Low, "A Tale of Two Citizenships," 74.

17 Marshall, "A British Sociological Career," 400.

18 Ibid.; T. H. Marshall, "Preface," in Marshall, Sociology at the Crossroads and Other Essays (London, 1963), vii-ix, at viii.

19 Box 1, 2/48, 51, 59 and Box 2, 2/766, in Maurice Ettinghausen Collection, Ruhleben Civilian Internment Camp Papers, 1914-37, Harvard Law School Library, transcript of Tape 429: Peter Liddle interview of T. H. Marshall, Feb.-March 1977, unnumbered in Liddle Collection (LC): RUH 33: Marshall Papers, Brotherton Library, Special Collections, University of Leeds (Brotherton).

20 Years later, Marshall remained in touch with fellow internees with fond stories about the camp song: "A Sequel to Ruhleben Memories," in 48 in MP 3/1, BLPES.

21 Matthew Stibbe, British Civilian Internees in Germany: The Ruhleben Camp, 1914-18 (Manchester, 2008), 81.

22 Marshall, "A British Sociological Career," 400. 
of the camp's day-to-day affairs, so that some of the internees, including Marshall, forged various organizations that shaped camp society. ${ }^{23}$

Marshall's experience at Ruhleben shaped his scholarship when he returned to Britain after the war. As he explained in letters home to his parents, he had come to see history as an "invaluable mental training." By contrast, philosophy now seemed "too abstracted from personal experience." 24 After four years in the camp, he returned to Cambridge, where he submitted a dissertation on seventeenth-century industrial development in England. As he explained in the preface, "My original intention was to examine the inner working of the guilds during the period of their decay. I have been led to speculate upon a deep and fundamental change in the industrial life of the nation." The dissertation outlined the transformation from local guild economies to a national, regulated economy with London as a driving force. The shift he described was not merely economic; it was also social. He decried that the "journeyman class of labour lost what standing it had possessed and was severed from the industrial society composed of capitalists and master-craftsmen." The charters of incorporation had "disinherited the working man." He concluded that seventeenth-century economic history "has the power to teach us much of the coming of national unity and the birth of that industrial division which has led to tyranny and suffering and the threat of class war." ${ }^{25}$

From Ruhleben, Marshall had brought not only a strengthened interest in history but also a preference for communal economies, which he saw as more egalitarian than those based on free markets. This sense of equality did not imply that all members of guild economies found the same financial status; instead, by sharing in local, communal life, they found a degree of equality of social status. His experience within the artificial society of the camp, reflecting on the various forms of society that developed within it, seemed to find expression in Marshall's historical sentiments about social relations and the impact of economic change. However, Continental social theory - and the early key works in the social sciencesdid not appear to inform this thinking. Nonetheless, like the pluralist George Unwin, who had also written about the transformation of industrial organization in the sixteenth and seventeenth centuries, ${ }^{26}$ Marshall seemed to owe an indirect

23 Transcript of Tape 429, unnumbered in LC: RUH 33, Brotherton.

24 T. H. Marshall, Letters IV, 28 Oct. 1916, 16 Feb. 1917, 3 March 1917, unnumbered in LC RUH 33, Brotherton. See also Low, "A Tale of Two Citizenships," 75-6.

25 Marshall, "A Survey of the Industrial Development of England from the Accession of James I to the Outbreak of the Civil War" (unpublished BA dissertation submitted to Trinity College, Cambridge, Aug. 1919), 2-3, 196-7, 203-4, 210, unnumbered in MP 4/1, BLPES.

26 George Unwin, Industrial Organisation in the Sixteenth and Seventeenth Centuries (Oxford, 1904). 
(and unacknowledged) debt to the German legal theorist Otto von Gierke. Gierke reconstructed the development of social groups in early modern Germany as a means to explain the specific trajectory of German legal and political history. ${ }^{27}$ By way of the historian Arnold Toynbee and the sociologist Herbert Spencer, Gierke's evolutionary emphasis on a teleology of national development seems to have influenced Unwin, who was part of a broader group of pluralists which drew on historical examples as a means to explain "Englishness." This line of thinking may also have informed Marshall's research on economic history, helping to lay the groundwork for his long-standing emphasis on the importance of heeding both national particularity and communal traditions when cultivating social rights. ${ }^{28}$

While Marshall did not refer to Gierke, he was influenced by the German economist Lujo Brentano, who espoused guild socialism as an ethical economic framework for the new German nation-state. ${ }^{29}$ In fact, Marshall's early historical research can be seen as an indication of his commitment to a particular form of ethical socialism. He even briefly (and unsuccessfully) dabbled in Labour politics in 1922, when he ran for Surrey's safe conservative seat in Parliament. ${ }^{30}$ To a certain extent, his thinking from this period echoed the various strands of pluralism embodied by G. D. H. Cole, R. H. Tawney, Harold Laski and other scholars on the left writing at the same time. ${ }^{31}$ For writers like Cole, pluralist associationalism offered an appealing alternative to the centralizing projects espoused by the Webbs. Over time, however, and especially with the onslaught of the Great Depression, even the most committed pluralists began to concede that some form of state action would be necessary to solve social problems. ${ }^{32}$ It was from this complex intellectual tradition that Marshall drew. For Marshall, it was possible to blend pluralism and idealism out of a commitment to ethical socialism, as can be seen in his early studies on economic history as well as in his later sociological

27 Otto von Gierke, Das Deutsche Genossenschaftsrecht, 4 vols. (Berlin, 1868-1913).

28 Julia Stapleton, "English Pluralism as Cultural Definition: The Social and Political Thought of George Unwin," Journal of the History of Ideas 52/4 (1991), 665-84.

29 In particular in T. H. Marshall, "Capitalism and the Decline of the English Guilds," Cambridge Historical Journal 3/1 (1929), 23-33. On pluralist links with German social philosophy see David Runciman, Pluralism and the Personality of the State (Cambridge, 1997), 64, 72, 168-73.

30 Marshall, "A British Sociological Career," 401.

31 For example, G. D. H. Cole, The World of Labour (London, 1913); R. H. Tawney, The Acquisitive Society (London, 1921); Harold Laski, Studies in the Problems of Sovereignty (London, 1917). See Marc Stears, Progressives, Pluralists and the Problems of the State: Ideologies of Reform in the United States and Britain, 1909-1926 (Oxford, 2006); Stefan Collini, Absent Minds: Intellectuals in Britain (Oxford, 2006), 93; Lawrence Goldman, The Life of R. H. Tawney: Socialism and History (London, 2013), 171-3.

32 Neil Riddell, “'The Age of Cole'? G. D. H. Cole and the British Labour Movement, 19291933," Historical Journal 38/4 (1995), 933-57. 
research, work on German reconstruction after the Second World War and at UNESCO in the 1950 s and early 1960 .

\section{THEORIZING THE STATE}

Marshall's synthesis of pluralism and idealism continued to inform his work after he left Cambridge in 1925 for a position as assistant lecturer in social science at the LSE. At the LSE, he continued to research and lecture on economic history while gradually deepening his commitment to sociology and more systematically theorizing the relationship between society and the state. ${ }^{33}$ Four years after taking up the post, he joined the sociology department and began teaching on comparative social institutions. ${ }^{34}$ With the outbreak of the Second World War, Marshall was driven back to an engagement with Germany and shifted his focus away from sociological research. However, he was able to apply his sociological thinking to his new occupation. In 1939, he joined Arnold Toynbee's Foreign Research and Press Service, which monitored the foreign press and advised the Foreign Office. Originally based at Balliol College, Oxford, it was later placed under the aegis of Chatham House in London as the Foreign Office Research Department (FORD). Marshall served as the head of the German section for the new department, submitting his first report, on “The 'Bolshevisation' of Germany," just a month into the war. Although members of the Foreign Office were skeptical of advice from that "woolly subject" sociology, they solicited a number of Marshall's memoranda on Germany during the war. ${ }^{35}$

For Marshall, the problem with Germany under National Socialism was that the state had become too powerful and too centralized-as well as too radical. Germany had lost sight of its legal, bureaucratic and communal traditions. As he explained in a 1941 memorandum, "Propaganda to Germany," Britain should aim to cultivate Germans' "instinctive loyalty to the quality of civilisation," not only by upholding Britain as a positive alternative to National Socialism but also by guiding Germans to look back to their pre-National Socialist heritage. ${ }^{36}$

33 Resulting in a string of early publications such as Marshall, "Capitalism and the Decline of the English Guilds"; T. H. Marshall, James Watt (London, 1925). He would continue to publish along these lines for the next several years: Marshall, "Jethro Tull and the 'New Husbandry' of the Eighteenth Century," Economic History Review 2/1 (1929), 41-60; Marshall, "Revisions in Economic History: II. The Population of England and Wales from the Industrial Revolution to the World War," Economic History Review 5/2 (1935), 65-78.

34 Halsey, "T. H. Marshall," 6.

35 T. H. Marshall, "The "Bolshevisation" of Germany," 19 Oct. 1939, 84-5 in Foreign Office Collection (FO) 371/23012, the National Archives (TNA); E. L. Woodward to Kirkpatrick, 14 Nov. 1939, 86-94, in FO 371/23012, TNA.

36 Memo by T. H. Marshall on "Propaganda to Germany," 14 July 1941, unnumbered in FO 371/26532, TNA; memo by T. H. Marshall, "Political Forces and Prospects in Germany," 26 April 1941, unnumbered in FO 371/26510, TNA. 
He argued, "we cannot re-educate Germany" because "the Germans have their own problems to solve, born of their own historic experience. We have ours; they are different, and we cannot claim that we know the solutions." ${ }^{37}$ With this in mind, he argued for creating a form of "utopia" in Germany after the war which would be based on "common sense." It would need to be "socialist" in nature, building on "local community and the individual," rather than the "state," and drawing on the "machinery" that was already in place in Germany since it was not "Nazi in origin." ${ }^{38}$ In his arguments, Marshall seemed to echo broader pluralist claims of the late nineteenth and early twentieth centuries about the value of associationalism in general. However, his views on German reconstruction also resonated with claims that Germany had historically been a model of organic community (Gemeinschaft) which contrasted with the impersonal society (Gesellschaft) that had emerged with urbanization and capitalism in the nineteenth century. ${ }^{39}$

In order to recover this past, but to take account of the significant demands of reconstruction, Marshall called for a "middle course." It would be characterized by neither what he saw as the "substitution of extreme individualism for economic planning, nor the substitution of unregulated international competition for economic autarchy." ${ }^{40} \mathrm{He}$ argued that relying on Germany's federal structure might enable Britain to foster this "middle course" in postwar Germany. ${ }^{41}$ Many years after his internment at Ruhleben and subsequent musings on guild socialism, Marshall, therefore, went back to calling for collective, communal forms of economic and social life, but he also saw the need to reconcile pluralism with the exigencies created by war. He recognized that National Socialism's attack on "individualism" and subordination of the individual to the collectivity had been too extreme, yet he still saw that individuals needed to play a role in communal life, which could, in turn, be fostered through Germany's federal state structure. ${ }^{42}$

These ideas about Germany following the war shed light on Marshall's views about the role of social policy in society. They highlight his ambivalence about planning a form of "utopia" and the need to search for a "middle course" which would be forged by a social community bound together in citizenship. As he

37 FORD memorandum by T. H. Marshall, "What to Do with Germany," 9 July 1942, 53, in MP $3 / 1$, BLPES.

38 Memo by T. H. Marshall on "Propaganda to Germany," 14 July 1941, unnumbered in FO 371/26532, TNA.

39 An argument made by the sociologist Ferdinand Tönnies, Gemeinschaft und Gesellschaft (Leipzig, 1887).

40 Marshall, "Propaganda to Germany."

${ }^{41} \quad$ T. H. Marshall, "Germany Today," for Civil Affairs Staff Centre: 2nd and 3rd Senior Officers' Course, n.d., 1 , in MP, $3 / 1$, BLPES.

42 Memo by T. H. Marshall, "Political Forces and Prospects in Germany," 26 April 1941, unnumbered in $\mathrm{FO}$ 371/26510, TNA. 
suggested, "we may do big things on a big scale after the war, but they will be inspired by common sense," not "ideologies." 43 Marshall conceded that a form of planning would be necessary for German reconstruction, just as it had been in Britain during the war. He argued, "we must show that we, too, are moving towards socialism, that is to say, towards social and economic planning, social equality and better social services." 44 Yet he emphasized that planning would need to take a non-radical form; it would need to be what he called, years later, "evolutionary" in nature, characterized neither by the conservatism of piecemeal reforms based on communal consensus that had typified Britain prior to the twentieth century, nor by the revolutionary, centralizing measures which were the hallmarks of fascism and communism. ${ }^{45} \mathrm{He}$ argued that Britain could provide a model for Germany's postwar reconstruction because "we are doing this without destroying individual liberty and the freedom of the mind, and without making the people the slaves of the State, and the servants of the State and the masters of the people. The aspect of democratic civilization which we have to stress is ... [that] we must dwell on civil liberties." 46

As Marshall suggested a few years later, he thought that intellectuals could play an important role in charting this course. Yet he was wary of the role of intellectuals in political life because they were indecisive and lacked a clear understanding of the parameters for political decision making, as had been evidenced, Marshall argued, by Franklin Roosevelt's "egg heads" in the United States. ${ }^{47}$ He was also wary about the scope of the state in these initiatives, although he did concede that social workers and social scientists could help to forge the gulf between state and society. ${ }^{48}$ Marshall declared, "we must make the Germans sick of the glorification of the national government, or Leader, and homesick for the less spectacular, but less dangerous and exacting, life of town, of village and of home." 49 He was skeptical of an entirely new course in planning for social and economic policy, as he preferred the foundations for social life that were

\footnotetext{
43 Marshall, "Propaganda to Germany."

44 Ibid.

45 T. H. Marshall, "Social Change in Britain: A Sociological Perspective," unnumbered in MP, 4/2, BLPES.

46 Marshall, "Propaganda to Germany." He reiterated these sentiments in a public lecture at the end of the war: T. H. Marshall, "Work and Wealth" (1945), in Marshall, Sociology at the Crossroads, 218-34, at 227.

47 Marshall, "Reflections on the Intelligentsia."

48 Marshall, "Work and Wealth," 227. Similarly, T. H. Marshall, "Welfare in the Context of Social Policy" (1964), in Marshall, The Right to Welfare and Other Essays (London, 1981), $67-82$, at 80 .

49 Author's italics. Marshall, "Propaganda to Germany."
} 
embodied within communities. In this regard, Marshall's thoughts on Germany during the war echoed the pluralist leanings of his early academic career.

\section{CHARTING SOCIAL CITIZENSHIP}

Marshall's reflections on the relationship between individuals, communities and the state in postwar Germany proved significant for his next major scholarly project: theorizing social citizenship for postwar Britain. He left FORD in 1944 in order to take up a position as head of the Social Work Department at the LSE. Although he toured West German universities in the winter of 1947-48 in a programme sponsored by the Association of University Teachers, he only returned to focusing on German reconstruction in the latter half of 1949, when he was made the educational adviser at the British Control Commission..$^{50}$ Six months prior to taking up that position, Marshall wrote his lectures on Citizenship and Social Welfare, which he gave at the University of Cambridge in honor of Alfred Marshall. He sought to provide a historical and sociological response to the problem posed by the eminent economist in 1873: "The question is not whether all men will ultimately be equal ... but whether progress may go on steadily ... till, by occupation at least, every man is a gentleman." ${ }^{11}$ T. H. Marshall saw that the question of "ends or ideals lies outside the field of social science and within the field of social philosophy." 52 In his lectures on citizenship, he therefore attempted to find a bridge between the two domains.

Marshall had begun his search for that bridge when he first joined the teaching staff at the LSE and concentrated his writing and teaching on problems of social class. This work evolved naturally from his earlier critique of the rise of class society as a result of the decline of guild economies. ${ }^{53}$ For example, in his 1938 series on "Class" for the National Programme of the BBC, he had continued to grapple with questions about social status and equality and argued that class distinctions had declined over the preceding century. "The tradition about the gentleman," he claimed, "has spread, in a slightly different form, down the social scale."54 In 1949 he continued to reflect on the legacy of the "gentleman" as he wrestled with finding an answer to Alfred Marshall's question. Before proceeding to answer it, however, Marshall suggested modifying the question by replacing

\footnotetext{
50 Marshall, "A British Sociological Career," 404.

51 Alfred Marshall, "The Future of the Working Classes," given at the Cambridge Reform Club in 1873, quoted in Marshall and Bottomore, Citizenship and Social Class, 4-5.

52 Marshall and Bottomore, Citizenship and Social Class, 3.

53 Marshall, "A British Sociological Career."

54 T. H. Marshall, "Class: An Enquiry into Social Distinctions," 13 Dec. 1938, given on the BBC National programme, 278-91, in MP 2/16, BLPES.
} 
"gentleman" with "civilised." The distinction was significant. He argued that Alfred Marshall saw "the standard of civilised life [to be] the conditions regarded by his generation as appropriate to a gentleman." In order to be accepted as "citizens," T. H. Marshall argued, all must "enjoy a share in the social heritage." Civility, and by extension the quality of being a citizen, was therefore a social fact that communities constructed; it was not an abstract ideal, nor was it universal..$^{55}$ In this sense, Marshall's 1949 lectures seemed to reflect both his observations of German society prior to the rise of National Socialism, which he praised for its communal and federal nature, and his earlier writings on guild economies.

He proposed that citizenship consisted of three elements: civil rights, characterized by negative freedoms such as the rights to association, free speech, freedom of religion and property ownership; political rights, centred on suffrage and democracy; and social rights, which were marked by positive freedoms such as the rights to education and to welfare benefits. These rights evolved over time, from "three strands ... wound in a single thread" to distinct entities that came into their own at particular junctures. According to Marshall, it was the eighteenth century that saw the turning point in this process, with the arrival of comprehensive civil rights, ${ }^{56}$ while the nineteenth century marked the era of political rights. It was Marshall's own century, the twentieth, that saw the predominance of social rights. ${ }^{57}$ Marshall gave his lectures in the summer of 1949, just one year after the inauguration of Britain's National Health Service and seven years after William Beveridge's renowned Report on Social Insurance and Allied Services declared war on the five "Giant Evils" of social life. According to Marshall's model, citizenship endowed members of a community with equality of social status that could coexist with inequality of material status. ${ }^{58}$ It seemed to provide a justification for the new universalist welfare state that had been erected through a series of legislation over the course of the 1940s. It also appeared to offer a democratic and capitalist alternative to the social engineering undertaken by the USSR that was beginning to extend across Eastern Europe.

With its claim that the twentieth century saw a "marked shift from duties to rights" based on social equality, Citizenship and Social Policy fostered an ideal type of welfare state. Marshall saw that the equality provided by citizenship would be so significant that it would make the inequality of social class acceptable. In effect, he saw that a new order of social status, based on rights rather than wealth, had transformed-and would continue to transform-British society in the twentieth

55 Marshall and Bottomore, Citizenship and Social Class, 6.

56 He did, however, concede that certain civil rights, such as habeas corpus, had a more ancient heritage. Ibid., 10.

57 Ibid., 8-10.

58 Ibid., 6-7. 
century. Yet this theory was not based on the premise of comprehensive planning or "social engineering" from above. When analyzing what he called "citizenship," Marshall was concerned with the process involved in forging what he saw as "a kind of basic human equality associated with the concept of full membership of a specific community." 59 In this sense, Marshall echoed a broader liberal tradition going back to his LSE mentor L. T. Hobhouse, who emphasized that "democracy is not founded merely on the right or the private interest of the individual. This is only one side of the shield. It is founded equally on the function of the individual as a member of the community." His theory of social citizenship also chimed with the ideas proposed by William Beveridge as well as a strand of the British postwar Labour movement which merged social-democratic, pluralist and liberal thought as an alternative to communism. ${ }^{60}$

For Marshall, the development of citizenship would require a combination of historical evolution along with legislative creativity. In these respects, Marshall's theory of citizenship connected with various elements of both pluralist and idealist social philosophy. On the one hand, like the idealist works of T. H. Green, it offered an alternative to a theological framework as the basis for social change. ${ }^{61}$ Marshall did not refer to a "general will" guiding the evolution of social rights, but he did view their development as a natural progression since feudalism. For Marshall, this progression was not a movement from "status" to "contract," as the legal theorist Henry Maine argued. Instead, Marshall saw that this evolution was more complex, as it was a shift from one form of status-based relations to another, from status based on birth and privilege, as was the case under feudalism, to that based on wealth under capitalism and finally to a new form of status based on social rights. ${ }^{62}$ The origins of social rights would emerge as the synthesis of earlier movements towards civil rights, on the one hand, and political rights, on the other. This triadic element of Marshall's theory had Hegelian undertones, although Marshall did not refer to idealist philosophers in his work.

On the other hand, Marshall echoed pluralists before him, both in his emphasis on social citizenship as embodied within community, and in his analysis of a specifically British historical path in forging social rights out of earlier civic and political rights. According to Marshall, the seeds for the progression towards social

59 Ibid., 6.

$60 \quad$ L. T. Hobhouse, Liberalism (London, 1919; first published 1911), 228; Peter Ackers and Alastair J. Reid, "Other Worlds of Labour: Liberal-Pluralism in Twentieth-Century British Labour History," in Ackers and Reid, eds., Alternatives to State-Socialism in Britain: Other Worlds of Labour in the Twentieth Century (Houndmills, 2016), 1-27.

61 Mark Bevir, "Welfarism, Socialism and Religion: On T. H. Green and Others," Review of Politics 55/4 (1993), 639-62.

62 Marshall and Bottomore, Citizenship and Social Class, 21, 24. 
rights were sown prior to the enormous political and economic changes which Karl Polanyi five years earlier had named "the great transformation." Marshall argued that social rights were "rooted in membership of the village community, the town and the guild" but had been "gradually dissolved by economic change until nothing remained by the [Elizabethan] Poor Law." ${ }^{63}$ Echoing his Cambridge dissertation, Marshall saw that the national, rather than local, nature of the Poor Law marked it as a new departure away from earlier conceptions of social rights. The twentieth-century predominance of social rights would, therefore, be a return of sorts to an aspect of earlier communal life-even if many of the rights Marshall outlined in his theory, including legal aid and education policy, were forged through national legislation.

For Marshall, the relationship between individual and community stood the core of the social rights which were embodied in citizenship. Although he argued that twentieth-century social rights marked a shift in balance between rights and duties, he conceded that individual duties towards the community remained. ${ }^{64}$ Echoing earlier idealist discussions about the role of individual "functions" within an organic community as well as a broader egalitarian-communitarian discourse amongst British progressives such as Tawney and Cole, he declared that paying taxes, insurance contributions and military service were obligations that existed alongside social rights. ${ }^{65}$ For Marshall, these duties were ethical, but they would also need to be compulsory, as "the community is so large that the obligation appears remote and unreal." In this way, he argued that duties acted as an "incentive" for the attainment of social rights, which should be seen as universal. ${ }^{66}$

A linchpin of Marshall's theory of social citizenship was, in fact, a duty: education. Following Alfred Marshall, and echoing nineteenth-century idealists, he claimed that the state must make education compulsory as a first step to assist individuals in self-realization. ${ }^{67} \mathrm{He}$ saw that education provided a "right to equality of opportunity" and espoused a meritocratic school system in which

\footnotetext{
63 Ibid., 9, 14-15.

64 A tension also highlighted by Michael Freeden: "Civil Society and the Good Citizen: Competing Conceptions of Citizenship in Twentieth-Century Britain," in Jose Harris, ed., Civil Society in British History: Ideas, Identities, Institutions (Oxford, 2003), 275-93, at 285-6.

65 Bevir, "Welfarism, Socialism and Religion"; Marshall and Bottomore, Citizenship and Social Class, 45; Ben Jackson, Equality and the British Left: A Study in Progression Thought, 1900-1964 (Manchester, 2007), 27, 40-41, 63, 183, 203-4.

66 Marshall and Bottomore, Citizenship and Social Class, 47-8.

67 Ibid., 5. He would reiterate this point in later works: T. H. Marshall, "The Right to Welfare" (1965), in Marshall, The Right to Welfare, 83-94, at 91; Marshall, "Welfare in the Context of Social Policy," 88.
} 
individuals could prove their abilities. Through education as well as housing, he argued that a balance might be struck between individual and collective rights, which he saw as a "matter of vital importance to the democratic socialist state." 68 Education was a duty because it allowed individuals to "improve and civilise" themselves, which was necessary because "a society depends upon the civilisation of its members" in order to cultivate "organic unity" and a "national heritage." 69 As he later elaborated on education, "the claims of the individual must always be defined and limited so as to fit into the complex and balanced pattern of the welfare of the community," with the result that "welfare can never have the full stature of a natural right." 70 In this respect, he built upon idealist thought about the relationship between individuals and collectivities, demonstrating the need for individual self-realization in order to benefit the community at large. ${ }^{71}$

Marshall's arguments about self-realization through education connected to a broader debate amongst the left in the 1940s and 1950 s about equality and about the role of the state in ensuring it. ${ }^{72}$ In his theory of citizenship, Marshall was grappling with the question of centralized state planning. His call for universal social rights paradoxically allowed for a civic minimum based on the specific customs of the community. The communal basis of social rights - as well as the scope allowed for individual self-realization-seemed to negate the possibility of state-driven social engineering. However, Marshall conceded the need for "planning" in order to ensure social mobility, in particular through education. He argued that the system set up by the 1944 Education Act may have created a new form of class system, based on scholastic ability, but "its advantages, in particular the elimination of inherited privilege, far outweigh its incidental effects." 73 As he later elaborated in a lecture for the Eugenics Society, the "welfare state ... believes in planning — not of everything but over a wide area." To be sure, planning would be necessary in the domain of education, where there was

68 Marshall and Bottomore, Citizenship and Social Class, 33, 35-6.

69 Ibid., 16.

70 T. H. Marshall, "Social Selection and the Welfare State" (Galton Lecture delivered at the Eugenics Society, 18 Feb. 1953), in Marshall, Sociology at the Crossroads, 245-66, at 247.

${ }^{71}$ He developed this notion in his later writings, arguing that social workers played a crucial role in assuring that social policy focuses on individuals. Marshall, "Welfare in the Context of Social Policy," 81.

72 Especially in the context of the 1944 Education Act that established free secondary schooling up to age fifteen. Marshall was one of several sociologists who took part in this discussion. Jackson, Equality, 165-6, 169, 189, 197, 203. For broader context see Peter Mandler, "Educating the Nation I: Schools," Transactions of the Royal Historical Society 24 (2014), 5-28.

73 Marshall and Bottomore, Citizenship and Social Class, 39. 
the potential for the "waste of money and effort by giving education and training to those who cannot get enough out of them to justify the cost."74

As he suggested in Citizenship and Social Class, "the planned or patterned society" was a natural form of social life which had been eliminated by the birth of the "competitive economy." By returning to "social rights," as embodied in older forms of communal life, Britain would also therefore return to a "patterned society."75 For Marshall, planning and older traditions of communitarianism were not incompatible; they were linked in a form of ethical socialism. In fact, while working at the LSE, Marshall had befriended Evan Durbin, who advocated connecting ethical socialism with planning and efficiency. ${ }^{76}$ In taking this view, Marshall seemed to echo Sidney Webb, who reconciled utilitarianism, economics and socialism..$^{77}$ At the same time, he built upon an earlier sociological tradition by advancing Émile Durkheim's investigations of "organic solidarity" and Max Weber's work on bureaucracy, even though Marshall cited neither. ${ }^{78}$ For Marshall, social citizenship brought together central planning and communal fellowship. Accordingly, the postwar British welfare state, which provided the foundation for social citizenship, could combine centralization with a kind of communitarian corporatism.

\section{FROM SOCIAL CITIZENSHIP TO DEMOCRATIC CITIZENSHIP}

Marshall saw that it was the amalgam between state and community which would have to take shape in postwar Germany in order to ensure that it developed as a democracy. As educational adviser at the British Control Commission (BCC), he spent eighteen months between 1949 and 1950 working on this goal while organizing the reconstruction of Germany's education system. Just as he had argued during the war while working at FORD, he continued to call for a return to Germany's pre-National Socialist heritage in order to pave the way to the

\footnotetext{
74 Marshall, "Social Selection and the Welfare State," 247-8, also 254.

75 Marshall and Bottomore, Citizenship and Social Class, 14.

76 Low, "A Tale of Two Citizenships," 97.

77 Jackson, Equality, 119, 152; Mark Bevir, "Sidney Webb: Utilitarianism, Positivism and Social Democracy," Journal of Modern History 74/2 (2002), 217-52.

78 I thank one of the anonymous reviewers for drawing my attention to this important point. David Lockwood, "For T. H. Marshall," Sociology 8/3 (1974), 363-7. Marshall, "A British Sociological Career," 95, claimed he would not "swallow either of them whole-to become a Durkheimian or a Weberian." He praised Weber's theory of bureaucracy later in his career, but did not apply it to his work. See T. H. Marshall, "World Congress of Sociology," New Society 1 (4 Oct. 1962), 24-6, at 25. However, he engaged with the concept of Herrschaft in The Right to Welfare, 137-56.
} 
country's future: "one passes, as it were, from a museum to a laboratory."79 Yet Marshall now conceived of an expanded role for Britain in the reconstruction of Germany. Like many others at the time, he saw that the "welfare state" in Britain offered a democratic and liberal alternative to fascist Germany's "warfare state." As Marshall explained in a lecture given on the BBC, he needed to emphasize to Germans that welfare was not "something to be achieved exclusively by direct state action and intervention in social life." After National Socialism, such an approach might seem "a threat to individual liberty."

Instead, welfare could be built through a combination of voluntary agencies working in conjunction with local, regional and national government. In this way, he claimed, "our social services [are] services offered by the community to the community, and not by the rich to the poor." The British welfare state, as envisaged in this pluralist but quasi-centralized incarnation, could thereby serve as a guide for Germany. ${ }^{82}$ In any case, it could provide a counterpoint to the centralized state that had been forged under National Socialism and was emerging in the USSR. For Marshall, as for many interwar and early postwar thinkers, pluralism seemed to offer the ideal alternative to totalitarianism because it was democratic. ${ }^{83}$ It was clear to Marshall and his colleagues at the BCC that democracy could be encouraged through culture, broadly conceived. In this respect, his views echoed those of many intellectuals and politicians working across interwar and postwar Germany such as those involved in the Cultural League for the Renewal of Democratic Germany and the America Houses. ${ }^{84}$

The reform of universities, alongside adult education, was central to Marshall's efforts in encouraging postwar German democracy. ${ }^{85}$ The task was a challenge, as his colleagues at the BCC, the Foreign Office and the Conference of Allied Ministers of Education (CAME) recognized. On the one hand, it seemed that Germany needed to be "civilized" in liberalism and democracy through education. This emphasis was a priority of the Potsdam Agreement of 1945: education seemed the best means to implement the combined goal of demilitarization, denazification, democratization and decartelization

79 T. H. Marshall, "Germany in 1950: The Choice between Yesterday and Tomorrow," presented on BBC Third Programme, 1-9, in MP, 2/17, BLPES.

80 David Edgerton, Warfare State: Britain, 1920-70 (Cambridge, 2006), 59-61.

$81 \quad$ T. H. Marshall, “The Welfare State: The Next Phase,” presented on BBC Third Programme, 88-104, in MP, 2/17, BLPES.

82 Ibid.

83 Jackson, Equality, 155-6o.

84 Sean Forner, German Intellectuals, 195-208; Greenberg, Weimar Century, 109-12.

85 Geoffrey Bird, "The Universities," in Arthur Hearnden, ed., The British in Germany (Bristol, 1978), 146-57; Harald Husemann, "Anglo-German Relations in Higher Education," in ibid., 158-73. 
in Germany after the war. In this sense, Britain could offer a model in terms of prioritizing independent, critical thinking, alongside a sense of social responsibility and commitment to one's community. On the other hand, trying to lay blame on Germans - or to emphasize "reeducation" as a quasi-colonial project—would only prove alienating and backfire. ${ }^{86}$ Managing this delicate balance would, therefore, require broader efforts in cultural diplomacy.

Although his position at the BCC was in education, Marshall saw his primary function as forging improved Anglo-German relations through cultural diplomacy. ${ }^{87}$ In order to encourage Germans' commitment to democracy, Marshall helped found the Königswinter Conferences in 1950 with the assistance of Chatham House and the Foreign Office. The conferences brought together about a hundred scholars, diplomats, politicians, industrialists and others as a means to "educate the new West German foreign policy elite" and integrate West Germany into European political and social life. Like Wilton Park, the conferences were intended to foster renewed Anglo-German relations, especially in the face of what seemed the growing threat of the Soviet Union. In this effort, as in his discussions about social welfare, he emphasized the role of the individual and community, rather than the central state, in reconstructing German democracy. Marshall's lecture on "Democratic Citizenship," delivered in Germany in the autumn of 1949, between his Cambridge lectures on Citizenship and Social Class and their subsequent publication, stressed the role of the "individual citizen," as well as his rights and duties, in shaping a democratic future in Germany. As Christian Haase has shown, that future was not, however, individualistic: it entailed individuals contributing in their multiple social roles, as spouses, parents, workers and citizens. ${ }^{88}$

After Marshall left his position at the BCC, he looked back at Germany as a success in reconstructing its lost communitarian traditions. Over the course of the 196os, amidst heated debate within Britain about reforming social provision, he looked to Germany again, and now in a new light: not as the object of British guidance on education and welfare, but rather as a model for Britain. He saw that

86 Francis Graham-Dixon, The Allied Occupation of Germany: The Refugee Crisis, Denazification and the Path to Reconstruction (London, 2013), 4-5; David Welch, "Priming the Pump of German Democracy: British 'Re-education' Policy in Germany after the Second World War," in Ian D. Turner, ed., Reconstruction in Post-war Germany: British Occupation Policy and the Western Zones, 1945-55 (Oxford, 1989), 215-38.

87 T. H. Marshall, Office of the Educational Adviser, Bielefeld, "Long-term Policy," 10 Jan. 1950, unnumbered in FO 1050/1156, TNA.

88 Christian Haase, "Democratic Citizenship in the Industrial Age: The British Sociologist T. H. Marshall and the Democratisation of West Germany," in Arnd Bauerkämper and Christiane Eisenberg, eds., Britain as a Model of Modern Society? German Views (Augsburg, 2006), 89-110, at 93-4, 98-9. 
Germany had come to pave an admirable middle course between the planning culture taken up by postwar France and Britain's stagnating welfare system. Marshall now argued that there was a general convergence across the world towards "planning" as part of the evolution of national economies. However, following his LSE colleague Karl Mannheim, he claimed that planning took different forms in different states. ${ }^{89}$ While Britain was "dithering" about the future of its social policy, its European counterparts had moved onwards, developing comprehensive programs that raced ahead of the universal but minimal assistance provided in the UK. What he appreciated about the European welfare systems was how they forged an "amalgamation" between the state and society, allowing a variety of actors, including employers and workers, to uphold the welfare state..$^{90}$ In the case of Germany, he saw that this system was, in part, the outgrowth of an established tradition of corporatism and an economy based on cartels. Yet he also claimed that this particular version of state-society relations, which lent itself towards "pluralism," was a response to excessive centralization under National Socialism. ${ }^{91}$ Ironically, this version of German welfare resembled what Marshall ten years earlier had sought to transfer from Britain to the devastated postwar country.

\section{HISTORY, UNIVERSALISM AND HUMAN RIGHTS}

Marshall's understanding of social citizenship was paradoxical in its combined emphasis on universal entitlements through the state and social rights derived from one's status as a member of a community. This emphasis emerged in his suggestions for the reconstruction of democracy in Germany and in his later musings on Germany as a model for the British welfare state in the 1960s. For Marshall, universalism denoted entitlement to social benefits and access to education, but it did not mean universal social rights that transgressed national borders. Nor was social citizenship a universal category; citizenship was founded within a national community, and aspects of citizenship went further down the chain of social relations, into the village and guild and their twentieth-century successors. His particularist thinking about social citizenship may offer some clues about his silence on both human rights and the legal status of citizenship in Britain. His Cambridge lectures on Citizenship and Social Class came after the

89 T. H. Marshall, "From Proto-industrial to Full Industrial," n.d., 1964-9, 52-61, in MP, 1/1, BLPES; Karl Mannheim, Diagnosis in Our Time: Wartime Essays of a Sociologist (London, 1944).

90 T. H. Marshall, “The Welfare State and the Affluent Society," n.d., 1964-9, 109-18, in MP, 1/1, BLPES. Similarly, see T. H. Marshall, Social Policy (London, 1965), 92-4, 179.

$91 \quad$ T. H. Marshall, "State, Time and Industrial: Power Rights," n.d., 1964-9, 77-93, in MP, 1/1, BLPES. Similarly, Marshall praises pluralist solutions in his Social Policy, 181-2. 
adoption of the British Nationality Act of 1948, which, in principle, granted British citizenship to the eight-hundred million members of the Commonwealth. Not least, he wrote the lectures just as the United Nations General Assembly released its Universal Declaration of Human Rights. In this light, Marshall's work on social citizenship might seem a natural response to broader discussions about the nature of rights in the postwar world, and his concept of social rights could be seen as both an analytical and a temporal precursor to human rights. ${ }^{2}$

However, his silence on the British Nationality Act reveals that, despite his commitment to political pluralism within Britain, he was not devoted to a vision of cultural pluralism. For Marshall, social citizenship was founded on a common community that was implicitly national and held a shared history. While each member of that community might have a different function within it, it went without question that all members of the community shared common cultural norms predicated on a combined commitment to equality of social status and the potential for self-realization. Marshall may have assumed, like many Britons in the late 1940s, that the Nationality Act would not alter the meaning of citizenship, which would continue to reflect the specific values and practices within the British Isles. ${ }^{93}$ To be sure, the Act was not introduced to encourage migration to Britain. Instead, the policy was a legal innovation needed to address the demands of movements in the Commonwealth that sought their own national citizenships by creating a new legal entity: the United Kingdom and Colonies. On paper, commonwealth citizens would share equal status with Britons until 1962. ${ }^{94}$ Nonetheless, the majority of Britons did not believe in 1948 that citizenship in Britain had changed meaningfully as a result of the policy..$^{95}$

For Marshall, as for other Britons in 1948, the main change to citizenship was the innovation of social citizenship, which had been forged through the common hardships of war and the creation of Britain's postwar welfare state. As he later recalled, postwar Britain would be "governed by the same principles of pooling and sharing that governed the emergency measures of the war." ${ }^{6}$ His view reflected a growing transatlantic consensus after the war. For example, Richard Titmuss's 1950 Problems of Social Policy argued that the war had changed the social

92 Stefan-Ludwig Hoffmann, "Viewpoint: Human Rights and History," Past \& Present 232/1 (2016), 279-310; Moyn, The Last Utopia; Lynn Hunt, Inventing Human Rights: A History (New York, 2007).

93 A point first raised by Jose Harris, "Citizenship in Britain and Europe."

94 Kathleen Paul, Whitewashing Britain: Race and Citizenship in the Postwar Era (Ithaca, 1997), 9-10, 17-18.

95 Randall Hansen, Citizenship and Immigration in Post-war Britain: The Institutional Origins of a Multicultural Nation (Oxford, 2000), 4.

96 T. H. Marshall, Social Policy in the Twentieth Century, ed. A. H. Halsey (London, 1985), 79. 
order and paved the way for universal welfare policies in Britain. ${ }^{97}$ Meanwhile, across the Channel, a former leader of the resistance and France's new minister of labour, Alexandre Parodi, declared in 1945 that the freedom won at the end of the war should now be extended to "social affairs" by addressing workers' rights. ${ }^{98}$ And, across the Atlantic, President Roosevelt had issued an economic bill of rights the previous year, declaring that "our fighting men abroad-and their families at home-expect such a program and have a right to insist upon it."99

Roosevelt's emphasis on economic rights also found expression in the Atlantic Charter of 1941, which laid out the Allied aims for the postwar world order. The eight points of the charter included rights to self-determination alongside "improved labor standards, economic advancement and social security." The charter was interpreted in various ways at the time and afterward, but came to be seen as a beacon of human rights. ${ }^{100}$ A few years later, several of its precepts could be found in the United Nations Universal Declaration of Human Rights (UDHR). Its twenty-second article declared, "Everyone, as a member of society, has the right to social security and is entitled to realization, through national effort and international co-operation and in accordance with the organization and resources of each State, of the economic, social and cultural rights indispensable for his dignity and the free development of his personality."101

The Declaration's call for both social security and self-realization chimed with Marshall's concept of social citizenship. It echoed his emphasis on a mixture of social rights and duties, including the duty to take up education. However, the UDHR was universalist, paving over any cultural, social and historical differences around the world. Not least, it called for international cooperation in social affairs; neither the state, nor the various associations and communities within it, were the central focus for welfare. The language of universalism signaled a turn away from the problems that beset the League of Nations in its focus on protecting minority rights. ${ }^{102}$ Yet it also seemed natural to the three main architects of the document, John Humphrey, Charles Malik and Roosevelt. As Samuel Moyn has

97 Richard M. Titmuss, Problems of Social Policy (London, 1950), 506-7.

98 Quoted in Eric Jabbari, Pierre Laroque and the Welfare State in Postwar France (Oxford, 2012), 127.

99 Quoted in James T. Sparrow, Warfare State: World War II Americans and the Age of Big Government (Oxford, 2011), 197.

100 Elizabeth Borgwardt, A New Deal for the World: America's Vision for Human Rights (Cambridge, MA, 2005).

101 Universal Declaration of Human Rights: at www.ohchr.org/EN/UDHR/Documents/ UDHR_Translations/eng.pdf, accessed 12 Jan. 2017.

102 Mark Mazower, “The Strange Triumph of Human Rights, 1933-1950," Historical Journal 47/2 (2004), 379-98. 
argued, their "worldviews" were "primarily defined" by Christianity, with its combined implications for social justice and universalism. Similarly, the Catholic publicist Jacques Maritain proved one of the declaration's leading advocates, as he saw natural law as the basis for human rights. ${ }^{103}$

It was already apparent when the UDHR was drafted that this model of universalism would not work in practice. Cultural norms about the family, in particular, seemed to get lost in translation. ${ }^{104}$ Not least, the idea of granting universal rights to current and former colonies, and to the segregated African American population in the United States, was unappealing. The document became a guideline and a source of inspiration. It was not, however, a binding piece of law. ${ }^{105}$ From this perspective, Marshall's silence on the UDHR in the late 1940 s and the 1950 s reflected broader ambivalences about both the language and the reach of human rights. As he argued in a later essay, after working for UNESCO as head of the Social Sciences Department from 1956 to 1960, it was difficult to speak of universal human rights because cultures across the world differed so markedly. ${ }^{106}$ For Marshall, any consideration of citizenship, with its implications of civil, political and social rights, would be historical and national rather than universal. Similarly, Julian Huxley, the prominent eugenicist and first director of UNESCO, elaborated a concept of "world citizenship" that was bound up in an earlier imperial logic. For Huxley, world citizenship was based on evolutionary progress that affected different societies at different rates. Moreover, nations and states, rather than a unified globe, were at the core of his vision, and also informed UNESCO's efforts at education across the world. ${ }^{107}$

These ideas about cultural specificity and, by implication, the limits of "social citizenship" as a common framework for action rather than a normative ideal were also reflected in Marshall's own work at UNESCO, for which he embarked on a tour to Lebanon, Egypt, Iran, India and Thailand in an attempt to spread the study of social science. Marshall's service at UNESCO was part of a broader trend in which the social sciences were deployed in order to chart and understand cultural difference. In the context of the early Cold War, disciplines including anthropology, psychology and sociology offered a means to smooth

\footnotetext{
103 Moyn, The Last Utopia, 52-74.

104 Mary Ann Glendon, A World Made New: Eleanor Roosevelt and the Universal Declaration of Human Rights (New York, 2001), 93, 141-2, 153-4.

105 Mark Mazower, Governing the World: The History of an Idea (London, 2012), 318.

106 T. H. Marshall, "International Comprehension in and through Social Science" (7 May 1959), in Marshall, Sociology at the Crossroads, 44-66, at 63. He cites as an influence here Richard McKeon, Human Rights: Comments and Interpretations (London, 1949), 31-2.

107 Glenda Sluga, "UNESCO and the (One) World of Julian Huxley," Journal of World History, 21/3 (2010), 393-418, at 396-8. See also Paul Betts, "Humanity's New Heritage: Unesco and the Rewriting of World History," Past \& Present, 228 (2015), 249-85.
} 
over tense international relations and assist with decolonization by encouraging intercultural understanding. In this context, anthropologists like Margaret Mead were roped in to assist with training government officials before they embarked on overseas missions. ${ }^{108}$ And, prior to joining UNESCO, Marshall offered a training programme for colonial officials at the LSE and the School of Oriental and African Studies (SOAS) in which he reflected on the "application of British social policy and institutions to colonial conditions." ${ }^{109}$

The question of the applicability of British social policy-and the social sciences more generally - to postcolonial conditions confounded Marshall at UNESCO. In Beirut he took part in negotiations to set up a new Institute of Sociology, and in India he joined a seminar consisting of representatives from the $\mathrm{UN}$, the ILO and the WHO, alongside various NGOs and government officials from across Southeast Asia, in order to discuss funding research into growing cities, and particularly those involved in steel production. He noted a "real desire to collaborate," especially with Thailand's Social Science Association, which had been set up in 1956. Nonetheless, after the tour, Marshall reflected how he "was struck by the difficulty of communicating UNESCO's ideas and wishes to the people whom they are intended to reach. Even when there is a central office for foreign aid, as in Cairo, communication is imperfect."110

The reflection echoed Marshall's earlier thinking on postwar reconstruction in Germany; it seemed that UNESCO's plans would need to be adapted to the historical traditions, needs and actors within specific communities. UNESCO could assist with international development by encouraging the growth of the social sciences abroad. However, local conditions would need to be taken into account, not least because different countries were at different stages of development. Following the 1962 World Congress in Sociology, he wrote approvingly of sociologists' newfound interest in development and consideration of national variations. Marshall noted,

It is generally agreed that the subject of development was for a long time neglected by sociologists. There was a reaction against the excessive preoccupation of 19th century thinkers with the problem and the injection into what should be an objective analysis of the evaluative concept of progress ... However, interest in long term trends of a fundamental, and possibly of a universal, kind has been revived, and value judgments in

108 Peter Mandler, Return from the Natives: How Margaret Mead Won the Second World War and Lost the Cold War (Cambridge, MA, 2013), 54-5, chap. 5.

109 He also headed the LSE Standing Committee on Colonial Studies in 1946. Quoted in George Steinmetz, "A Child of the Empire: British Sociology and Colonialism, 1940s1960s," Journal of the History of the Behavioral Sciences, 49/4 (2013), 353-78, at 371-2.

110 T. H. Marshall, "Report of Mission to Beirut, Teheran, New Delhi, Calcutta, Bangkok and Cairo: 26 Oct. to 25 Nov. 1959," 3 Dec. 1959, 17-41, in MP 3/2, BLPES. 
terms of "advanced" and "underdeveloped" countries, or of "higher" and "lower" forms of socio-economic organization, are not excluded. ${ }^{111}$

In that light, the question remained "whether there can be any general theory of social development, or even whether the same concepts can be used in all cases. Are there any precedents for the situation in ex-colonial countries?" He considered his own typology for the development of social citizenship in postwar Britain and argued that it could not be applied easily to developing countries:

We need not expect to find there the English sequence of the rule of law, parliamentary democracy and the welfare state. Welfare has become a worldwide aspiration, and the administrative apparatus through which it can be achieved is known to all. So we can find cases where the right to welfare is pushed forward ahead of the full realization of individual liberty and political democracy. ${ }^{112}$

Over time, Marshall grew uneasy about the effectiveness of the UNESCO's work, sending the director general a couple of years later a memo with "Thoughts on Some Problems of Unesco." He noted, "an organization can carry out a successful mission for peace, truth, justice and human rights if all its members agree about the fundamental nature of these ideals. With UNESCO's present membership, such agreement is impossible. There can only be common acceptance of a form of words, which different member states interpret differently."113 Despite Marshall's doubts about UNESCO's overall mission, he saw that its work in education was valuable, and he continued to organize student exchanges between Eastern and Western Europe, as well as the establishment of the education system in Nigeria, over the next several years. In this way, he proselytized education, and with it sociology, as a possible ticket to fostering mutual understanding, as well as social and economic development, around the world. ${ }^{114}$ Espousing universal human rights or social rights was not, however, a priority.

\section{SOCIOLOGY AS SOCIAL PHILOSOPHY}

What is noteworthy about Marshall's thoughts on development and human rights, and going back to his 1949 Cambridge lectures on citizenship, was how

111 Marshall, "World Congress of Sociology," 25.

112 Ibid.

113 T. H. Marshall to Vittorino Veronese, director general of UNESCO, 26 June 1960, 42-7, in MP $3 / 2$, BLPES.

114 T. H. Marshall, notes on visit to Nigerian universities, 16-31 May 1962, 1-11, in MP 3/2, BLPES; T. H. Marshall to André Bertrand, director, Dept. of Social Sciences at UNESCO, 30 Dec. 1964, 48-51, in MP 3/2, BLPES; T. H. Marshall, "International Cooperation in the Social Sciences," UNESCO Report Papers on the Social Sciences 21 (1964), 52-4, in MP 3/2, BLPES. 
they coincided with his views about sociology as a discipline. Foreshadowing Robert King Merton's oft-cited call for theories of the "middle range," Marshall declared in his 1946 inaugural lecture at the LSE that the discipline should offer "stepping stones of the middle distance." Later, at the 1962 World Congress of Sociology, he spoke approvingly of the decline of "extreme" theoretical positions, arguing, "commonsense seems to be prevailing over dogmatism." 15 His philosophy for sociological practice reflected a qualitative, historical approach which incorporated theory with evidence from the past and present alike. ${ }^{116}$ In the same vein, Marshall argued for a "middle course" in German postwar reconstruction and later implied that Britain should take a similar path in the forging of its welfare state by following a line between communitarianism and central planning. Similarly, his triadic theory of citizenship was predicated on the synthesis of civil rights and political rights in the twentieth century, which would find expression in social rights. However, those social rights were not universal; instead, they were embedded within a national framework. In sociology, as in his own research and activities in reconstruction and development, he argued for neither grand theory nor detailed quantitative studies. At the LSE, Marshall was seen as a middle-range social theorist, in contrast to some of his colleagues, and a member of the "old guard" together with Mannheim and Morris Ginsberg. ${ }^{117}$ Their views on sociology could be found in the early days of the British Sociology Association, which had been established in 1950 and included historians, art historians, political scientists and others who were interested in sociology as a synthetic, humanistic subject. ${ }^{118}$

For this reason, Marshall sometimes questioned the direction sociology began to take from the 1950s. Several of his colleagues at the LSE and the new "plateglass" universities that had set up progressive sociology departments in the UK turned their attention to studying social class. In this respect, Marshall's own research interests were carried on in new scholarship. Seminal works focused on growing working-class affluence. For example, David Lockwood wrote on The Blackcoated Worker (1958), Lockwood and John Goldthorpe published The Affluent Worker (1968), and Goldthorpe later published Social Mobility in Modern Britain (1980). Giddens's theoretical work on structuration also fits within this

115 Marshall, "World Congress of Sociology," 25

116 T. H. Marshall, "Sociology at the Crossroads" (1946), in Marshall, Sociology at the Crossroads, 3-24, at 13. Robert K. Merton, "On Sociological Theories of the Middle Range," in Merton, Social Theory and Social Structure (New York, 1949), 39-53.

117 Ralf Dahrendorf, A History of the London School of Economics and Political Science, 1895 to 1995 (Oxford, 1995), 196-205; Payne, Sociology and Social Research, 23.

118 Savage, Identities, 130. 
trend. ${ }^{119}$ Meanwhile, Norman Dennis analyzed a Yorkshire mining community in his 1954 Coal Is Our Life, while Michael Young at the Institute of Community Studies undertook empirical research in Bethnal Green in order to trace the relationship between family, community and social services. Young's emphasis on community and kinship as a means to overcome the social dislocation of industrialism chimed with Marshall's own pluralist arguments. Together with Richard Titmuss and Peter Townsend, Young was part of a "mutualist and organicist strand of left-wing political thought in the 1950s." ${ }^{\prime 20}$ Moreover, several social scientists, including Titmuss and the economist Brian Abel-Smith, followed Marshall in international development work through projects funded by the UN, the ILO and other organizations. ${ }^{121}$

However, the methods of this younger generation, based on large data gathered through surveys and interviews, alongside pre-formed hypotheses, garnered criticism from more established scholars, including Marshall. ${ }^{122}$ Marshall noted, "a marriage of techniques cannot give rise to a science. Something more is needed ... for technique without science is inevitably driven to use what Bates calls the 'flip-flop' type of explanation, which is not derived in any way from the research itself nor drawn from a system of theory and ordered knowledge." Instead, it "is tailored expost facto to fit the data, even if this means that it must be turned inside out because the facts discovered are the reverse of those anticipated in the hypothesis." ${ }^{223}$ For example, Marshall cited W. G. Runciman's Relative Deprivation and Social Justice, claiming that his mixed methods failed to account for changing concepts of deprivation over time. ${ }^{124} \mathrm{He}$ noted that colleagues at the new universities should heed his warning about the use of data, though he singled out Noel Annan at King's College London as an example of bad practice. Without an appropriate analytical framework, they would be practicing "social studies" rather than "sociology."125

11 Mike Savage, “The Fall and Rise of Class Analysis in British Sociology, 1950-2016," Tempo Social 28/2 (2016), 57-72.

120 Lise Butler, "Michael Young, the Institute of Community Studies and the Politics of Kinship," Twentieth Century British History 26/2 (2015), 203-24, at 205.

${ }^{121}$ Sally Sheard, The Passionate Economist: How Brian Abel-Smith Shaped Global Health and Social Welfare (Bristol, 2014).

122 Savage, Identities, 130. Recent work on the history of sociology in Britain has confirmed these critiques: Jon Lawrence, "Social-Science Encounters and the Negotiation of Difference in Early 1960s England," History Workshop Journal 77 (2013), 215-39.

${ }^{123}$ T. H. Marshall, "Opportune, Salutary and Depressing: The Origins of Scientific Sociology by John Madge," New Society 44 (1 Aug. 1963), 26.

124 T. H. Marshall, "How Equal Can We Get?", New Society 7 (6 Jan. 1966), 28.

125 Marshall, "Opportune, Salutary and Depressing." 
Despite these qualms, Marshall saw value in the new sociological methodsif used carefully - and supported his junior colleagues at the LSE. His impact on the discipline continued to find admirers amongst the younger generation of scholars, giving rise to the annual Marshall lecture series at Southampton University two years after his death in $1981 .{ }^{126}$ Sociological methods may have transformed, but Marshall's ideas-on class, history and universalism, social citizenship and community, and a balance between theory and empiricismlived on. In turn, into the late twentieth century, sociological research continued to be informed by nineteenth-century and interwar ideas drawn from idealism and pluralism, derived from Continental philosophy and transatlantic exchanges about rights, and shaped in the context of two world wars.

\section{CONCLUSIONS}

In the "age of extremes" that marked the first half of the twentieth century, neither idealism nor pluralism disappeared. Instead, as the case of T. H. Marshall shows, they were recast out of the experiences of war, reconstruction and decolonization and offered a means to make claims about liberalism and social democracy that contrasted with fascism, communism and some of the centralized planning within European postwar democracies. By placing the work of sociologists like Marshall within the international and imperial context in which they lived, we can glean deeper insights into this European and transatlantic intellectual history. ${ }^{127}$ This approach enables us to move beyond seeing Marshall's Cambridge lectures primarily as a hallmark of the postwar years and as a programmatic statement of the values of political consensus in Britain-even if that consensus was more of a myth than a reality. ${ }^{128}$ And it allows us to transcend seeing his understanding of social rights solely as a manifestation of the widespread "middle opinion" about planning, individualism and collectivism that evolved in Britain over the $1930{ }^{129}$ Not least, it encourages us to see sociologists-like other scholars - not as members of a static stage in the evolution of a discipline but rather as intellectuals whose work evolved in step with their complex biographies and the broader histories in which they lived.

126 Bulmer and Rees, Citizenship Today.

127 For a related approach see George Steinmetz's important forthcoming monograph as well as his edited collection Sociology and Empire: The Imperial Entanglements of a Discipline (Chapel Hill, 2013).

128 Harriet Jones and Michael D. Kandiah, eds., The Myth of Consensus: New Views on British History, 1945-64 (Basingstoke, 1996).

129 Arthur Marwick, "Middle Opinion in the Thirties: Planning, Progress and Political Agreement," English Historical Review 79 (1964), 285-98. 
Marshall's vision of social citizenship resonated most clearly not with the particulars of the postwar moment, but rather with his earlier musings on guild socialism, pluralism and the problems of the state in Germany. And yet his understanding of social rights also echoed his "stepping stones" in sociology. Sociology would take Britain neither "towards the sky" not "into the sands." "130 Instead, it would run along a "middle course," not unlike that which he had outlined for postwar Germany. These views, together with T. H. Marshall's transnational biography, throw new light on how postwar reconstruction, alongside its global legacy in the form of UNESCO, worked within a European context. On the one hand, Marshall's international experiences and his national background were related and mutually influential. On the other, his life and writings show the continued sway and reconstruction of social thought after 1945 that had been prominent in the nineteenth century. Nineteenth-century ideas that had been formed in a context of nation and empire building could easily extend to a twentieth-century age of extremes characterized by war, new forms of democratic politics and transnational efforts at reconstruction and postcolonial development.

By the late 1960s and early 1970s, this longue durée of European thought about social citizenship, with its implications for the special roles of individuals, communities and nations, had begun to wither away. In its place emerged new sociological methods alongside the breakdown of UNESCO's utopian education projects. The rise of a new era of grassroots human rights campaigns, from Doctors without Borders to Amnesty International, sought to recast the world neither as a universal project carried out in the name of cosmopolitanism, nor within the fixed remit of national cultures, traditions and communities. By the 1980s, efforts at retrenchment across much of Western Europe and the US seemed to indicate that Marshall's evolutionary understanding of social citizenship, and the broader heritage from which it derived, had reached a final climax. Nonetheless, the legacy of these ideas continued to inform conceptions of welfare policy and global development, casting a shadow over ongoing debates about the roles of individuals and communities and the balance between universalism and particularism.

\footnotetext{
130 Marshall, "Sociology at the Crossroads," 13.
} 